\title{
Extraction and purification of lipopolysaccharide from Escherichia coli (local isolate) and study its pyrogenic activity
}

\author{
A.M. Al-AAlim ${ }^{1}$, A.A. Al-Iedani ${ }^{2}$ A and M.A. Hamad $^{1}(\mathbb{C}$ \\ ${ }^{1}$ Department of Microbiology, College of Veterinary Medicine, University of Mosul, Mosul, ${ }^{2}$ Department of Microbiology, \\ College of Veterinary Medicine, University of Basrah, Basrah, Iraq
}

\begin{tabular}{l} 
Article information \\
\hline Article history: \\
Received November 16, 2020 \\
Accepted February 09, 2021 \\
Available online October 15, 2021 \\
\hline Keywords: \\
E. coli \\
Lipopolysaccharide \\
Hot-phenol extraction \\
SDS- PAGE \\
Pyrogenic activity \\
\hline Correspondence: \\
A.M. Al-AAlim \\
ammarmahmmod@uomosul.edu.iq
\end{tabular}

\begin{abstract}
In this study, we tried to extract and purify the LPS from E. coli local isolate and determine the molecular weight, purity, and pyrogenic effect of the product and compare it with standard E. coli O55:B5 LPS, the E. coli LPS was extracted by using hot phenol method then SDS- PAGE was used with both Coomassie blue and silver nitrate stain to determine its molecular weight and protein contamination also we used HPLC to the estimation of $E$. coli LPS purity and finally the pyrogenicity of extracted E. coli LPS was tested by using rabbit pyrogen test. The result showed that the hot phenol method with enzymatic treatment gave highly pure LPS with a high yield reach up to $242.4 \mathrm{mg}$, staining the SDS page gel with Coomassie blue and silver nitrate uncover the high purification of the extracted LPS (ELPS) with no protein contamination, with a molecular weight range between 15-23 kDa, HPLC test reveals that purity of ELPS was $100 \%$ compared with standard LPS. The rabbits' pyrogen test confirmed that the biological activity of ELPS. In conclusion, the LPS was extracted with high purity compare with standard LPS and without any protein or DNA contamination by using the hot phenol method also the extracted rough LPS was slightly lighter than the standard LPS used but this did not affect its biological activity which remained intact.
\end{abstract}

DOI: 10.33899/ijvs.2021.128963.1614, (CAuthors, 2022, College of Veterinary Medicine, University of Mosul.

This is an open access article under the CC BY 4.0 license (http://creativecommons.org/licenses/by/4.0/).

\section{Introduction}

Enterobacteriaceae family is a large diverse group of Gram-negative rods considered as normal flora in the intestinal tract of both animals and humans (1). Escherichia coli the wide world distribute bacteria belong to this family and could be found in food and cause infection in human and animals (2-5), according to virulence, pathogenicity, and site of infection $E$. coli is classified as commensal, enteropathogenic, and extraintestinal pathotypes strains (610). All Gram-negative bacteria are enveloped by a cell wall consisting of the cytoplasmic inner membrane, an intermediate layer of peptidoglycan, periplasm layer, and finally, outer membrane layer $(11,12)$ which connected covalently to peptidoglycan by lipoprotein (13). E. coli outer membrane composed of phospholipid and lipopolysaccharide which reflected the inner and outer layer of the membrane. The main components of lipopolysaccharide LPS are lipid A, core oligosaccharide, and $\mathrm{O}$ - antigen. All compartments help to protect the bacteria and play role in antigenic variation, both lipid A and core oligosaccharide involved in bacterial virulence, and $\mathrm{O}$ - antigen also has attachment properties as well as acts to resist many antimicrobial drugs and phagocytosis effect (12). The O- antigen alone capable to protect the bacteria from lytic action of complement and bacteriophage $(14,15)$. There were different protocols for extraction and purification of bacterial LPS these protocols differ in their yield and purity such as Trichloroacetic acid, Aqueous butanol, Triton $/ \mathrm{Mg}^{+2}$, Aqueous ether, Chloroform: methanol: petroleum-ether, and EDTA method. The hot phenol extraction method was mostly used due to the short 
time required with high yield production. $(16,17)$. The LPS of Enterobacteriaceae is characterized by its high molecular weight ranging from $10-100 \mathrm{kDa}$ and the most LPS of smooth $E$. coli strain reach up to $25 \mathrm{kDa}(1,17-19)$.

Bacterial LPS (endotoxin) consider as a potent pyrogen which means that have the ability to induce fever with several pathophysiological effects after injected intravenously; only a very small quantity (Nanogram $/ \mathrm{kg}$ ) of LPS was able to stimulate the response of an immune system and exaggerated host response to the removal of this toxic substance from body circulation by releasing many types of mediators that mediated in pyrogenic response. (20) the liberation of LPS from the cell wall in the host relates to a wide range of bad effects such as releasing of pro-inflammatory cytokine as TNF- $\alpha$, IL-1 by macrophages which were responsible for fever production and lead to hyperthermia as a result of the pyrogenic response, and lead to inflammation, capillary leak, tissue toxicity (21) coagulation (22), aseptic shock, lethality (12). The aims of this study, is to extract and purify the LPS from E. coli local isolate, determine the molecular weight and pyrogenic effect of the extracted LPS (ELPS), and compare it with standard LPS(SLPS) purified from E. coli O55: B5 as a positive control.

\section{Materials and methods}

\section{E. coli bacterial isolate and purity determination}

Three Shiga Toxigenic E. coli (STEC) local isolates which isolated from cattle in Basrah governorate were gifted from the Department of Microbiology and Parasitology, University of Basrah, College of Veterinary Medicine (23). The purity of the isolates was confirmed by culturing on brain heart infusion broth, Eosin Methylene Blue agar, and MacConkey agar at $37^{\circ} \mathrm{C}$ for $24 \mathrm{~h}$. The isolates were confirmed using polymerase chain reaction PCR. Briefly, five single colonies from each isolate were selected for DNA extraction using DNeasy ${ }^{\circledR}$ Blood and tissue Kit (Qiagen, USA) kit and amplification of uid $A$ gene. The PCR conditions were set as similar to that described by (24). The final PCR product was detected in $2 \%$ agarose using $60 \mathrm{~V}$ for $1.5 \mathrm{~h}$ and the band was visualized by using a transilluminator $(23,25)$ the amplicon size was 623 bp according to (24).

\section{Preparation of bacterial isolate}

For extraction of lipopolysaccharide. five single colonies of STEC were transferred from eosin methylene blue agar to tubes containing $5 \mathrm{ml}$ brain heart infusion broth and incubated aerobically at $37^{\circ} \mathrm{C}$ for $24 \mathrm{~h}$, then the bacterial growth turbidity was adjusted with $0.5 \mathrm{McFarland}$ standard tubes to obtain $1.5^{*} 10^{8} \mathrm{CFU} / \mathrm{ml}$ as starting bacterial inoculum. The suspension was transferred to one liter of brain heart infusion broth and incubated aerobically at $37^{\circ} \mathrm{C}$ for $24 \mathrm{~h}$. The final bacterial turbidity was adjusted to 1.84 by spectrophotometer using $\mathrm{OD}=600 \quad \mathrm{~nm}$ this approximately equal to $2 * 10^{9} \quad \mathrm{CFU} / \mathrm{ml}$. E. coli lipopolysaccharide was extracted by using the hot phenolwater method described by (16) with some minor modifications. in our study 4 patches (Each patch represented 1 liter of $E$. coli culture $\left(2 \times 10^{9} \mathrm{CFU} / \mathrm{ml}\right)$ was used for extraction LPS from E. coli local isolate, bacterial suspension in each patch was collected by cold centrifuge at $4100 \mathrm{rpm} / 15 \mathrm{~min}$, after washing the bacterial pellet with phosphate buffer saline (PBS) $\mathrm{pH}=7.2$, contain $0.15 \mathrm{mM}$ $\mathrm{CaCl}_{2}$ and $0.5 \mathrm{mM} \mathrm{MgCl}$; the pellet was resuspended in 10 $\mathrm{ml}$ of PBS, to liberate the LPS in solution, the bacterial cells in suspension were destroyed by sonication $(29 \mathrm{MHz} /$ $10 \mathrm{~min})$. The next steps including treatment of sonicated bacterial suspension with $100 \mu \mathrm{g} / \mathrm{ml}$ Proteinase $\mathrm{K}$ in $65^{\circ} \mathrm{C} / 1 \mathrm{~h}$ to remove the protein contamination farther enzymatic treatment was extended to overnight at $37^{\circ} \mathrm{C}$ with $40 \mathrm{ug} / \mathrm{ml}$ RNase, $50 \mathrm{ul}$ of working solution of DnaseI (2U/ $\mu \mathrm{l}), 1 \mu \mathrm{L} / \mathrm{mL} 20 \% \mathrm{MgSO}_{4}$ and $4 \mu \mathrm{L} / \mathrm{mL}$ chloroform to remove any DNA or RNA contamination. The separation of LPS was done by adding an equal volume of hot $\left(65-70^{\circ} \mathrm{C}\right)$ $90 \%$ phenol and incubate the mixture in $70^{\circ} \mathrm{C} / 15 \mathrm{~min}$ with vigorous shaking, the LPS mixture was cooled in ice and centrifuged at $10000 \mathrm{rpm} / 15 \mathrm{~min}$ to separate aqueous phase from the phenolic phase, the phenolic phase was re extracted with $300 \mu 1$ distilled water, all aqueous phase was collected in $15 \mathrm{ml}$ conical centrifuge tube and the LPS was precipitate in $-20^{\circ} \mathrm{C}$ overnight after adding $0.5 \mathrm{M}$ (final concentration) of sodium acetate and 10 volume of $95 \%$ ethanol then the LPS was collected by centrifuge in $4^{\circ} \mathrm{C}$ at $4100 \mathrm{rpm} / 10 \mathrm{~min}$ and resuspended in $1 \mathrm{ml}$ distill water, for farther purification and removal of any chemical substance extensive dialysis against double distilled water occur in $4^{\circ} \mathrm{C} / 48$ hours using $13 \mathrm{~cm}$ long Dialysis tube (3500D cutoff value, $34 \mathrm{~mm}$, Special laboratory, USA) (26), the final step was lyophilized The purified LPS under $-55^{\circ} \mathrm{C}$ in 0.001 mbar for 24 hours then stored at $4^{\circ} \mathrm{C}$ for farther analysis.

\section{Detection of impurities of protein and nucleic acids}

Two $\mu 1$ of ELPS from $E$. coli were used for electrophoresis in $2 \%$ agarose containing ethidium bromide for detection of any DNA and/or RNA contaminants. However, the sodium dodecyl sulfate-polyacrylamide gel electrophoresis (SDS-PAGE) was used according to (2729) to determine the purity of the product from protein residues and the detection of the molecular weight of LPS. The SDS-PAGE gel was stained with both instant Blue ${ }^{\mathrm{TM}}$ (expedeon, UK) for detection of protein $(26,29-31)$ and sensitive silver stain (26,31-34) to visualized both protein contamination and the lipopolysaccharide.

\section{Analysis of extracted LPS by High-performance liquid chromatography}

High-performance liquid chromatography (HPLC) was used to identify and quantify the components of the mixture 
of ELPS and comparing with SLPS of E. coli O55: B5 $\left(\mathrm{Chem} \mathrm{Cruz}^{\odot}\right)$. Separation of both Lipopolysaccharide done by HPLC 1200 series system (Agilent Technologies, USA pressure $110 \mathrm{bar}$, and flow rate $0.8 \mathrm{ml} / \mathrm{min}$ with $210 \mathrm{~nm} \mathrm{UV}$ wavelength detector, the column Supelco ${ }^{\text {TM }}$ C18 of $25 \mathrm{~cm}$ length $\times 4.6 \mathrm{~mm}$ inner diameter, $5 \mu \mathrm{m}$ pore size was used for separation of Lipopolysaccharide), the mobile phase consisted from acetonitrile and water in concentration 5:95. $10 \mu \mathrm{l}$ from both standard and extracted LPS were injected into the HPLC for analysis $(16,35,36)$. The purity of the product was calculated as follows: The purity of sample $=$ (area under the peak of the test sample/ area under the peak of standard) $\times 100$. When it reaches $90-115$ this indicates high purity of the sample.

\section{Detection of the biological activity of extracted LPS}

Six white albino rabbits weighing $1.5-2 \mathrm{Kg}$ were used in the pyrogen test, animals were divided into three groups. The first group was the negative control group and the rabbits were given normal saline, the rabbits in the second and third groups were given an intravenous injection of 10 $\mu \mathrm{g} / \mathrm{kg}$ of both standard $E$. coli O55: B5 LPS and extracted $E$. coli LPS respectively. Rectal temperature before and after injection was recorded in all groups in the period interval of 30 mint up to 4 hours by using a medical rectal thermometer. The positive result was recorded as elevated in body temperature by $1-2{ }^{\circ} \mathrm{C}(20,26)$.

\section{Results}

The E. coli isolates were confirmed by amplification of uid $A$ gene using conventional PCR and separated in agarose gel, and the results confirmed the presence of uid $A$ gene with 623 bp product size (Figure 1).

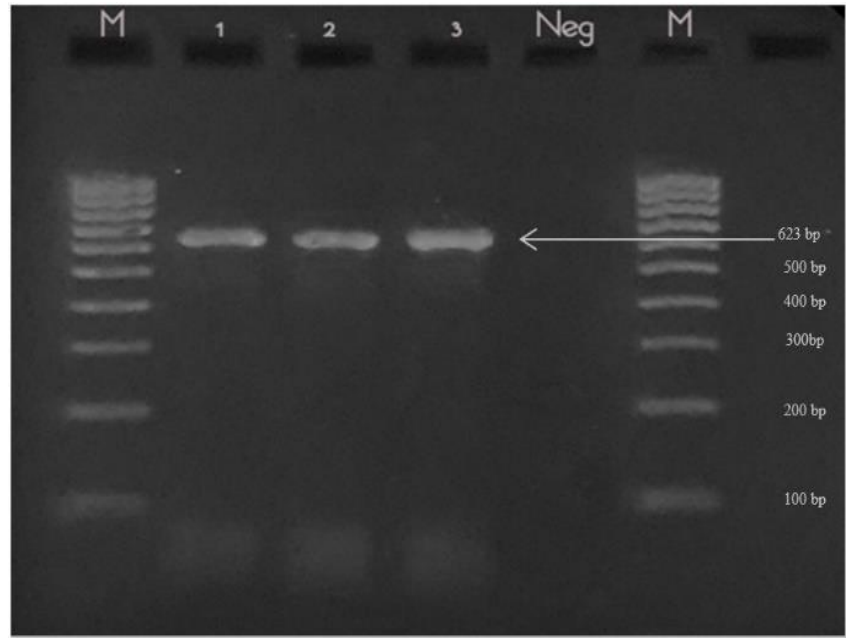

Figure 1: Escherichia coli uid A gene (M: ladder 100 bp, 1, 2 and 3: Shiga toxigenic E. coli).

\section{Extraction of $E$. coli lipopolysaccharide}

The results of the hot phenol extraction method used to isolate the LPS from - E. coli cultures $\left(2 \times 10^{9} \mathrm{CFU} / \mathrm{ml}\right)$, showed that the bacteria gave about $242 \mathrm{mg}$ of purified LPS after dialysis. The difference in the percentage of ELPS purification before and after dialysis was about $29.76 \%$ (Table 1).

Table 1: Percentage of E. coli LPS lost in the extraction and purification procedure

\begin{tabular}{lcccc}
\hline & \multicolumn{3}{c}{ Weight of crude LPS (mg) } & \\
\cline { 2 - 4 } $\begin{array}{l}\text { Patch } \\
\text { No.* }\end{array}$ & $\begin{array}{c}\text { before } \\
\text { dialysis }\end{array}$ & $\begin{array}{c}\text { after } \\
\text { purification } \\
\text { by dialysis }\end{array}$ & $\begin{array}{c}\text { lost during } \\
\text { purification }\end{array}$ & Lost $\%$ \\
\hline 1 & 10 & 6 & 4 & $40 \%$ \\
2 & 148 & 124.1 & 23.9 & $16.14 \%$ \\
3 & 147 & 88.2 & 58.8 & $40 \%$ \\
4 & 40 & 24 & 16 & $40 \%$ \\
\hline Total & 345 & 242.3 & 102.7 & $29.76 \%$ \\
\hline * Each patch represented 1 liter of E. coli & culture $2 \times 10^{9}$ \\
CFU/ml. & &
\end{tabular}

\section{Detection of DNA and RNA contaminants}

The ELPS was separated in agarose gel to detect the presence of any traces of nucleic acids (DNA and RNA). All patches of extracted LPS were 100\% free from nucleic acid contaminants due to the effect of DNase and RNase added during the extraction procedure (Figure 2).

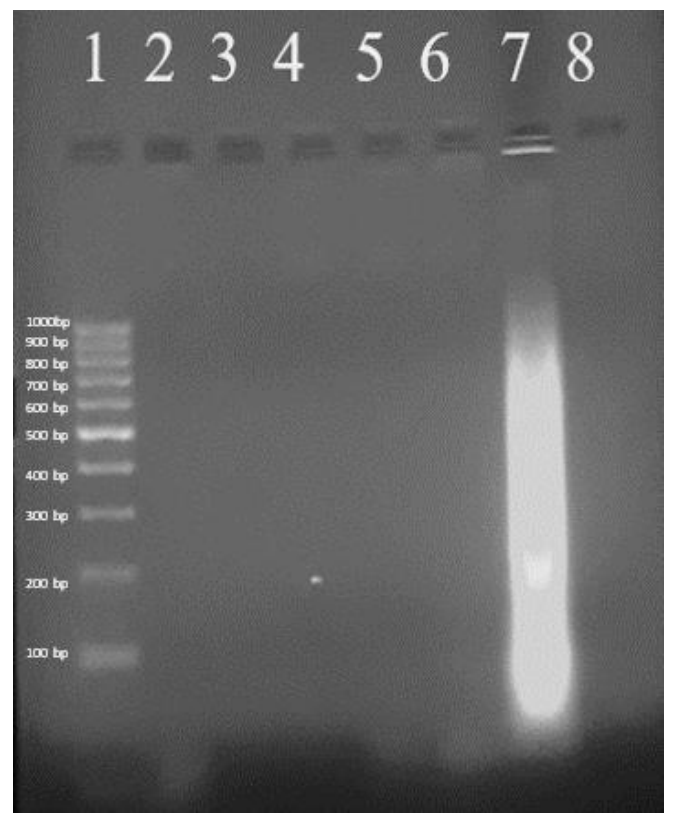

Figure 2: Extracted LPS of STEC in agarose gel (1: molecular weight marker, 2-6: ELPS, 7: bacterial suspension after sonicating and before DNase and RNase enzymes digestion, 8: negative control). 


\section{Detection of protein contaminants}

The SDS-PAGE electrophoresis followed by staining with instant Blue (Coomassie blue-based) stain specific for protein was used to detect any residues of protein in LPS extract. The extracted LPS was $100 \%$ free from protein contaminants (Figure 3).

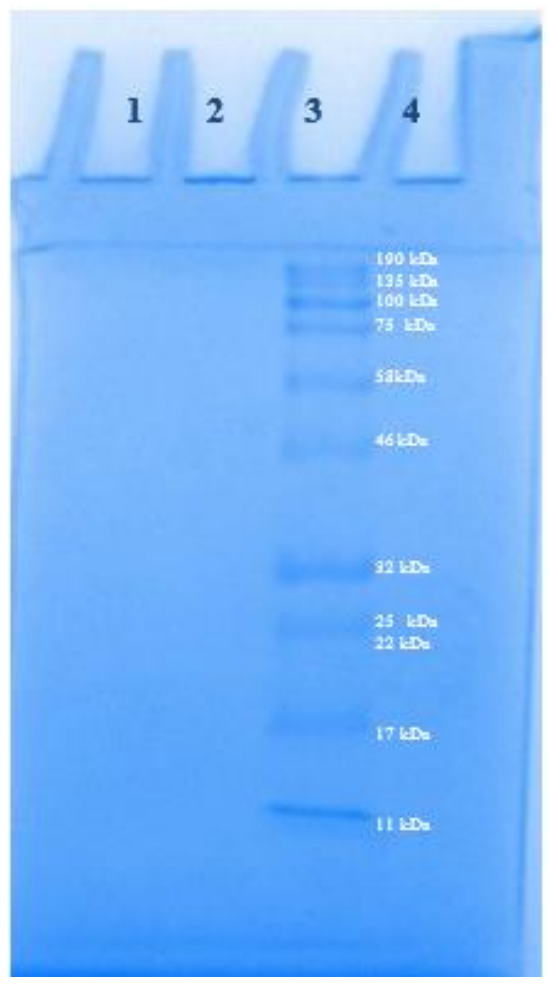

Figure 3: Electrophoresis of ELPS on SDS -PAGE (1: ELPS, 2: Standard LPS of E. coli O55: B5, 3: Protein weight marker [11-190] kDa, 4: negative control).

\section{Detection of the molecular weight and structure of extracted LPS}

The result of SDS-PAGE electrophoresis which was stained with sensitive sliver stain for LPS shows that the ELPS has three-bands with molecular weights ranged $(15,20$ and 32$) \mathrm{kDa}$, however, the standard LPS molecular weights ranging between (15-50) $\mathrm{kDa}$. The upper bands represent rough O-polysaccharide containing LPS (30-50) $\mathrm{kDa}$, the ELPS lighter than that of standard E. coli O55: B5 LPS, while the lower bands of both extracted and standard LPS represent the core lipopolysaccharide with lipid A and have molecular weights (15-20) $\mathrm{kDa}$. The intensity of the band was different when using different concentrations of LPS injected in the SDS-PAGE. The intensity of the bands was the best with $20 \mathrm{ng} / \mu \mathrm{l}$ followed by $100 \mathrm{ug} / \mu \mathrm{l}$ then $500 \mathrm{ng} / \mathrm{ml}$ as in (Figure 4). The addition of $4 \mathrm{M}$ Urea in resolving gel was not effective in-band separation but it gives more clear background gel.
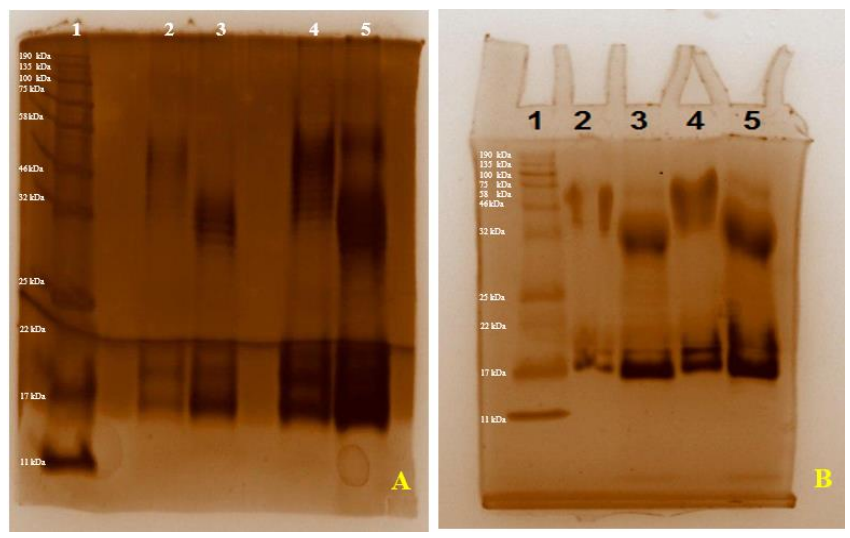

Figure 4: SDS-PAGE of the standard and extracted lipopolysaccharide from $E$. coli stained with the silver stain. A: (1: protein marker, 2: 20ng/ $\mu$ l standard E. coli O55:B5 LPS,3: 20ng/ $\mu 1$ Extracted E. coli LPS,4:100ng/ $\mu 1$ standard E. coli O55:B5 LPS,5: 100ng/ $\mu 1$ Extracted $E$. coli LPS). B: (1: protein marker, 2: $1.7 \mathrm{ug} / \mu 1$ standard $E$. coli O55:B5,3 LPS: $1.7 \mathrm{ug} / \mu 1$ Extracted $E$. coli LPS,4:500ng/ $\mu 1$ standard $E$. coli O55:B5 LPS, 5: 500ng/ $\mu 1$ Extracted E. coli LPS,4) upper band show rough O-polysaccharide containing LPS and lower band show core lipopolysaccharide with lipid A.

\section{Detection of purity of extracted $E$. coli LPS using HPLC analysis}

The purity of extracted $E$. coli LPS was analyzed by HPLC method using both extracted E. coli LPS and standard E. coli O55: B5 LPS, the result shows the appearance of one single peak with different retention time which reaches 1.650 in extracted $E$. coli LPS and 1.829 for standard E. coli O55: B5 LPS (Figure 5). The purity of ELPS was $100 \%$ in comparison with a standard.
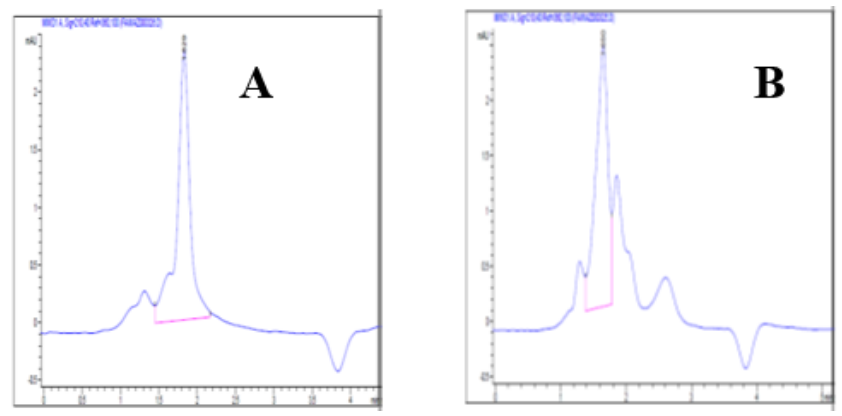

Figure 5: HPLC electropherograms of standard E. coli O55:B5 LPS (A) and extracted E. coli LPS (B).

\section{Detection of pyrogenic activity of extracted $E$. coli LPS}

The rabbit pyrogen test was used to detect the pyrogenicity of ELPS and SLPS by intravenous injection into the rabbits. The body temperatures reached $39.9^{\circ} \mathrm{C}$ and $40.6^{\circ} \mathrm{C}$ of the ELPS and SLPS respectively in comparison with the temperature of the control rabbit $38.5^{\circ} \mathrm{C}$ (Figure 6). 


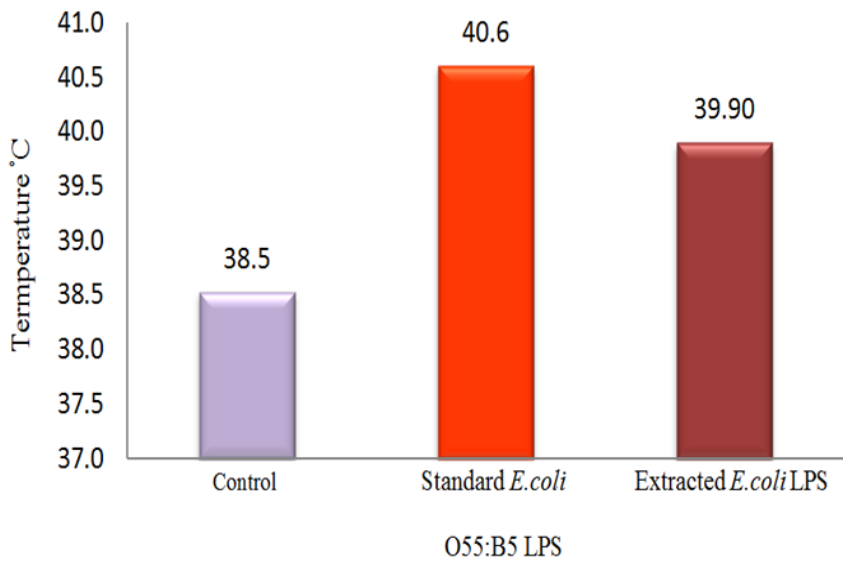

Figure 6: The mean body temperature of rabbits after intravenous injection with $10 \mu \mathrm{g} / \mathrm{kg}$ of $E$. coli LPS.

\section{Discussion}

The LPS also called endotoxin, is an essential structural part of the $E$. coli cell wall, as control permeability, antibiotic resistance, and further of its role as a structural component also it can modulate the immune response so play an important role in parasite-host interaction (15).

Many methods were used to extract the LPS with keeping high purity and biological activity as Trichloroacetic acid, Aqueous butanol, Triton $/ \mathrm{Mg}+2$, Aqueous ether, Chloroform: methanol: petroleum-ether, and EDTA method (37) and hot-phenol extraction method. The hot-phenol extraction method still the best method used although it has many dangerous and poisoning materials as phenol (26). The result of this study shows a high yield of $242.3 \mathrm{mg}$ of purified LPS from 4-liter of $E$. coli cultures with a mean $60 \mathrm{mg} / \mathrm{liter}$. These results were different from other related studies (17,26,37-39) and this difference in LPS yield maybe explain by differences in extraction methods and differences of Gram-negative bacterial species $(40,41)$.

Most methods used to extract bacterial LPS were not given a high purity LPS and many proteins and nucleic acid contaminants were found in ELPS, the hot phenol method was not excluded from this disadvantage and may contain up to $24 \%$ of RNA (36). The results of this study show that the LPS product was $100 \%$ free from protein in Coomassie blue staining and nucleic acid contaminants. these results were in agreement with that recorded by $(16,26)$ who used the proteinase $\mathrm{k}$ and DNase and RNase enzymes during the hot phenol extraction method.

The results of SDS-PAGE electrophoresis stained with silver stain showed that a more clearly detectable band was found in LPS concentration 20ng/ $\mu \mathrm{l}$ and this agrees with (34), the sliver stain was highly sensitive to detection of LPS. The effect of the addition of urea on the SDS-page does not affect the separation of the band but is believed to give more clear ground of gel as its increased oxygen permeability and water vapor transmission rate (42). The ELPS product has both rough and smooth parts of LPS, molecular weight ranged from $15-32 \mathrm{kD}$ in comparison with standard LPS used which have $15-50 \mathrm{kD}$ which lie in the standard molecular weight of LPS ranged between 2$100 \mathrm{kD}(1,17,18)$.

The difference in molecular weight between standard and ELPS may be due to differences between bacterial strains which have different LPS structures to give $E$. coli five core types K1, R1- R4 (19,43). The ladder formation appeared in rough LPS and this can explain by increasing of polysaccharide unit in the rough LPS core (44) as a modification of core LPS by adding more galactose, rhamnose, PEtN, or Kdo group as a response to stress or to increase bacterial resistance to the antimicrobial peptide $(15,45)$.

The HPLC result confirms the high purity of ELPS by showing only one sharp peak in comparison with the standard LPS this result agrees with (16) as a result of using enzymes to remove all contamination from ELPS. The most important in any extraction method is to preserve the biological activity of LPS, and its purity at a high level by removing chemical materials (used in the extraction process), protein, DNA, or RNA that affect and interfere with the signal downstream of biological and immunological responses (26).

The rabbit pyrogenic test was performed to evaluate the biological effect of the product, results showed that the mean rise of rabbit temperature was $1.4{ }^{\circ} \mathrm{C}$ which give the test a positive result and indicate the biological activity of the extra pure E. coli LPS and this agrees with $(20,46)$.

This elevation in animal's body temperature related to bacterial LPS which considered as a potent trigger for the immune system and capable to produce pro-inflammatory cytokine such as TNF $\alpha$, IL1 as well as Prostaglandin E2 that mediated in the production of pyrogen reaction and appear its biological effect $(16,20,21)$.

\section{Conclusion}

In conclusion, the LPS was extracted with high purity compare with standard LPS and without any protein or DNA contamination by using the hot phenol method also the extracted rough LPS was slightly lighter than standard LPS used but this did not affect its biological activity which remained intact.

\section{Acknowledgment}

The Authors are thankful for the efforts and support of the head of the Department of Microbiology and Deanship of the College of Veterinary Medicine, University of Mosul. 


\section{Conflict of interest}

The authors declare no conflict of interest with any official institute and this research was achieved without any financial support from any third party. We announce that the manuscript has been read and approved by all named authors and the order of authors listed in the manuscript has been approved by all of us.

\section{References}

1. Brooks GF, Carroll CK, Butel SJ, Morse AS, Mietzner AT. Medical microbiology. 26 ${ }^{\text {th }}$ ed. USA: McGraw-Hill eBooks Publisher; 2013. 229-245. [available here]

2. Neamah AJ, Al-Yassari AS, Hamed M, AlRammahi MA. Inhibition of Escherichia coli biofilm formation by Streptomyces sdLi crude extract. Iraqi J Vet Sci. 2020;34(2):305-310. DOI: 10.33899/ijvs.2019.125965.1202

3. Naji HA, Saleh WMM, Hanoon M, Imad I, Salim Y. Serotyping, virulence gene expression and phenotypic characterization of $E$. coli O157:H7 in colibacillosis affecting buffalo calves in Basra governorate. Iraqi J Vet Sci. 2019;33(2):447-451. DOI: 10.33899/ijvs.2019.163198

4. Klaif S F, Saleh ZF, Hussein MT, Jawad AA, Jawad MS. Molecular characterization of enterohemorrhagic E. coli $\mathrm{O} 157$ and O153isolated from tissue camel and human stool samples in Al-Diwaniyah, Iraq. Iraqi J Vet Sci. 2019;33(1):81-86. DOI: 10.33899/ijvs.2019.125530.1052

5. Al-Sharook MN, Hassan AA. Isolation and identification of extendedspectrum beta-lactamase (ESBL)-producing Escherichia coli from broiler in Erbil, Iraq. Iraqi J Vet Sci. 2017:31(1):31-38. DOI: 10.33899/ijvs.2017.126717

6. Ibrahim HM. Constructed of phylogenetic tree for Escherichia coli causing mastitis in Basrah province [master's thesis]. Basrah: College of Veterinary Medicine University of Basrah. 2018.

7. Gupta SK and Sharma A. Dynamic properties of Escherichia coli. World J Pharm Pharm Sci. 2015;4(7):296-307. [available at]

8. Hussain T. An introduction to the serotypes, pathotypes and phylotypes of Escherichia coli. Inter J Microbiol Allied. 2015:2:9. [available at]

9. Scott MD, Kennedy M, Chengappa MM. Veterinary microbiology. $3^{\text {rd }}$ ed. UK: John Wiley \& Sons; 2013. 62-74. [available here]

10. Abdul-Razzaq MS, Abdul-Lateef LA. Molecular phylogeny of Escherichia coli isolated from clinical samples in Hilla, Iraq. African J Biotechnol. 2011;10(70):15783-15787. DOI: 10.5897/AJB11.1273

11. Morè N, Martorana AM, Biboy J, Otten C, Winkle M, Serrano CKG, Silva AM, Atkinson L, Yau H, Breukink E, Den Blaauwen T. Peptidoglycan remodeling enables Escherichia coli to survive severe outer membrane assembly defect. Mol Biol. 2019;10(1):1-18. DOI: 10.1128/mBio.02729-18

12. Sampath V. Bacterial endotoxin-lipopolysaccharide; structure, function and its role in immunity in vertebrates and invertebrates. Agricult Nat Resources.2018:52(2):115-120. DOI: 10.1016/j.anres.2018.08.002

13. Mayer C, Kluj RM, Muhleck M, Walter A, Unsleber S, Hottmann I and Borisova M, Bacteria's different ways to recycle their own cell wall. Inter J Med Microbiol. 2019;309(7):151326. DOI: 10.1016/j.ijmm.2019.06.006

14. Putker F, Bos MP, Tommassen J. Transport of lipopolysaccharide to the gram-negative bacterial cell surface. FEMS Microbiol Rev. 2015;39(6):985-1002. DOI: 10.1093/femsre/fuv026

15. Bertani B, Ruiz N. Function and biogenesis of lipopolysaccharides. EcoSal Plus. 2018;8(1):1-33. DOI: 10.1128/ecosalplus.ESP-0001-2018

16. Rezania S, Amirmozaffari N, Tabarraei B, Jeddi-Tehrani M, Zarei O, Alizadeh R, Masjedian F, Zarnani AH. Extraction, purification and characterization of lipopolysaccharide from Escherichia coli and Salmonella typhi. Avicenna J Med Biotechnol. 2011;3(1):3-9. [available at]

17. Al-Musleh RM, Jawad Th A. Extraction and purification of lipopolysaccharide from Citrobacter fruendii and determination molecular weight with its carbohydrates, protein contain. J Karbala Uni. 2009;7(4):246-253. [available here]

18. Hulko M, Dietrich V, Koch I, Gekeler A, Gebert M, Beck W, Krause B. Pyrogen retention: Comparison of the novel medium cut-off (MCO) membrane with other dialyser membranes. Sci Rep. 2019;9(1):1-7. DOI: $10.1038 / \mathrm{s} 41598-019-43161-2$

19. Stenutz R, Weintraub A, Widmalm G. The structures of Escherichia coli O-polysaccharide antigens. FEMS Microbiol Rev. 2006;30(3):382-403. DOI: 10.1111/j.1574-6976.2006.00016.x

20. Elkhateeb MA, Elkhatib W, Aboulwafa M. An expert review on current approaches for endotoxin detection in various biological products. Arch Pharmaceut Sci Ain Shams Uni. 2019;3(2):142-153. DOI: 10.21608/APS.2019.13058.1000

21. Hung YL, Suzuki K. The pattern recognition receptors and lipopolysaccharides (LPS)-induced systemic inflammation. Int J Res Stud Med Health Sci. 2017;2:1-7. [available here]

22. Stief TW. Coagulation activation by lipopolysaccharides. Clin Appl Thromb .2009;15(2):209-219. DOI: 10.1177/1076029607309256

23. Farhan Z, AL-Iedani A. Molecular detection of shiga toxin (stx1 and stx2) and intimin (eae A) genes in Escherichia coli isolated from fecal samples of cattle, sheep, and human in Basrah governorate. Basrah $\mathbf{J}$ Vet Res. 2019;18(2):288-305. [available at]

24. Moyo SJ, Maselle SY, Matee MI, Langeland N, Mylvaganam H. Identification of diarrheagenic Escherichia coli isolated from infants and children in Dar es Salaam, Tanzania. BMC Infect Dis. 2007;7(1):92-99. DOI: 10.1186/1471-2334-7-92

25. Sambrook HC. Molecular cloning: A laboratory manual. New York: Cold Spring Harbor; 1989. 1-1441.

26. Kalambhe DG, Zade NN, Chaudhari SP. Evaluation of two different lipopolysaccharide extraction methods for purity and functionality of LPS. Inter J Curr Microbiol App Sci. 2017;6(3):1296-1302. DOI: 10.20546/ijcmas.2017.603.150

27. Mcilwaine C, Strachan A, Harrington Z, Jerreat M, Belfield LA, Sandor V, Foey A, Zaric S. Comparative analysis of total salivary lipopolysaccharide chemical and biological properties with periodontal status. Arch Oral Biol. 2020; 110:104633-104639. Doi:10.1016/j.archoralbio.2019.104633

28. Laemmli UK. Cleavage of structural proteins during the assembly of the head of bacteriophage T4. Nat. 1970;227(5259):680-685. DOI: $\underline{10.1038 / 227680 \mathrm{a} 0}$

29. Arqam A. Biophysical and kinetic analysis of Escherichia coli DNA ligase activity and inhibition [PhD dissertation]. Portsmouth: University of Portsmouth, UK; 2018.

30. Beer LA, Speicher DW. Protein detection in gels using fixation unit 10.5. Curr Protoc Protein Sci. 2019;21(91):10-51. DOI: $\underline{10.5 .20 .10 .1002 / \mathrm{cpps} .48}$

31. Chowdhury FA, Islam MN, Saha A, Mahboob S, Mosaddek ASM, Faruque MO, Begum MF, Bhattacharjee R. Purification, extraction and visualization of lipopolysaccharide of Escherichia coli from urine samples of patients with urinary tract infection. Avicenna J Clin Microbiol Infect. 2015;2(4):31990-31990. DOI: 10.17795/ajcmi31990

32. Li H, Yang T, Liao T, Debowski AW, Nilsson HO, Fulurija A, Haslam SM, Mulloy B, Dell A, Stubbs KA, Marshall BJ. The redefinition of Helicobacter pylori lipopolysaccharide O-antigen and core-oligosaccharide domains. PLoS Pathogens. 2017;13(3):1-21. DOI: $10.1371 /$ journal.ppat.1006280

33. Li H, Benghezal M. Crude preparation of lipopolysaccharide from Helicobacter pylori for silver staining and Western blot. Bio Protoc. 2017;7(20):1-8. DOI: 10.21769/BioProtoc.2585

34. Tsai CM, Frasch CE. A sensitive silver stain for detecting lipopolysaccharides in polyacrylamide gels. Analyt Biochemist. 1982;119(1):115-119. DOI: 10.1016/0003-2697(82)90673-X 
35. Fadel MA, Hassan HM. Validated method for extraction and purification of Lipopolysaccharide from Escherichia coli and Salmonella by HPLC. Anim Healt Res J. 2019;7(3):1-10. [available here]

36. Zankharia US, Desai PV. Chemical analysis of lipopolysaccharide extracted from Salmonella enterica serovar typhi. IJRSI. 2015;II(VI):75-78. [available here]

37. Al-Masalmawi TH, Al-Khafji MSH. Study of some chemical and biological properties of Lipopolysaccharide extracted from Pseudomonas aeruginosa: First scientific conference of pure science educational college. Karbala Uni J. 2012;1:242-252. [available here]

38. Nile RS, Darweesh MF, Al-Rufaie MM. Liposomallipopolysaccharide vaccine extracted from Proteus mirabilis induces moderate TLR4 and CD14 production. Curr Iss Pharm Med Sci. 2019;32(2):81-86. DOI: 10.2478/cipms-2019-0016

39. Luchi M, Morrison DC. Comparable endotoxic properties of lipopolysaccharides are manifest in diverse clinical isolates of gramnegative bacteria. Infect Immunit. 2000;68(4):1899-1904. Doi: 10.1128/IAI.68.4.1899-1904.2000

40. Ebrahimi Z W, Mousavi G S, Rajabi b M, Mohamadi M, Vaise M Z. Comparison of different LPS extraction methods for isolation of smooth and rough LPS. First International and $12^{\text {th }}$ Iranian congress of Microbiology. Kermanshah. Iran; 2011 23-26. [available here]

41. Uchida K, Mizushima S. A simple method for isolation of lipopolysaccharides from Pseudomonas aeruginosa and some other bacterial strains. Agricul Biol Chem. 1987;51(11):3107-3114. DOI: 10.1080/00021369.1987.10868532

42. Schmid M, Prinz TK, Stabler A, Sangerlaub S. Effect of sodium sulfite, sodium dodecyl sulfate, and urea on the molecular interactions and properties of whey protein isolate-based films. Frontiers Chemist. 2017;4:1-10. DOI: 10.3389 /fchem.2016.00049

43. Ebbensgaard A, Mordhorst H, Aarestrup FM, Hansen EB. The role of outer membrane proteins and lipopolysaccharides for the sensitivity of Escherichia coli to antimicrobial peptides. Frontiers Microbiol. 2018;9:.2153-2172. DOI: 10.3389/fmicb.2018.02153

44. Ismail HA. Study on virulence factors of salmonella isolated from patients in Kirkuk city and compared with some standard isolate $[\mathrm{PhD}$ dissertation]. Mosul: College of Science, Mosul University, Iraq; 2005

45. Mazgaeen L, Gurung P. Recent advances in lipopolysaccharide recognition systems. Inter J Molecul Sci. 2020;21(2):379-397. DOI: 10.3390/ijms21020379

46. Al-Sultany SJ, Jassim YA. Physiological and immunological effect of lipopolysaccharide of Escherichia coli was extracted by hot phenolwater in rabbits. Res J Pharmaceut Biol Chem Sci. 2016;7(3):15301535. [available here]

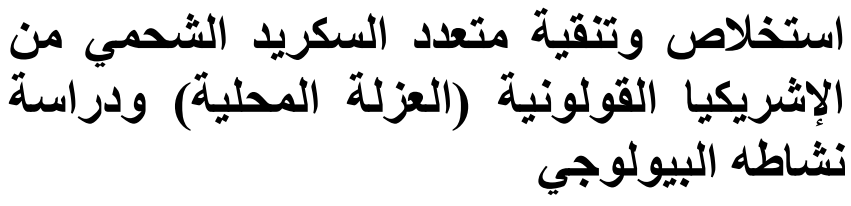

\author{
عمار محمود العالم'، علي عبود العيدانَ و محمد علي حمد' \\ 'فرع الأحياء المجهرية، كلية الطب البيطري، جامعة الموصل، \\ الموصل، 'جامعة البصرة، البصرة، العراق البرة البرة

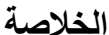

تهدف الدراسة الحالية إلى استخلاص وتتقية متعدد السكريد

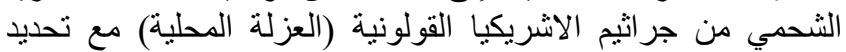

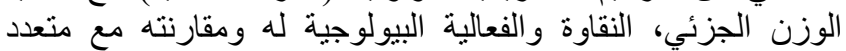

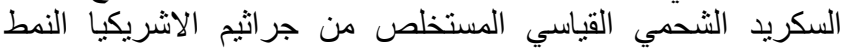

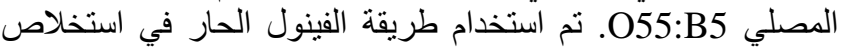

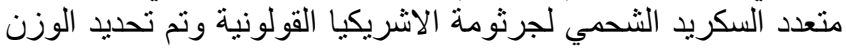

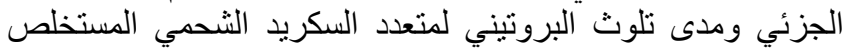

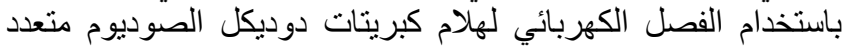

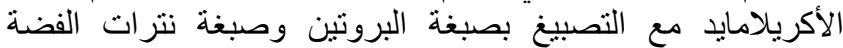

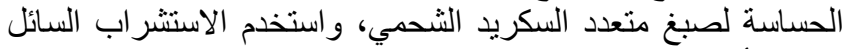

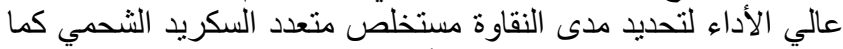

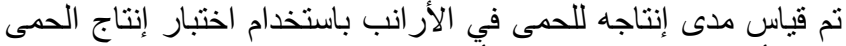

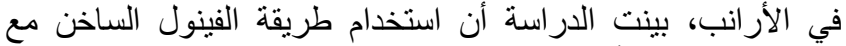

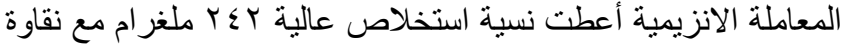

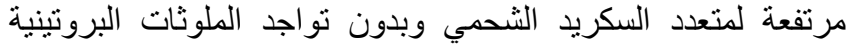

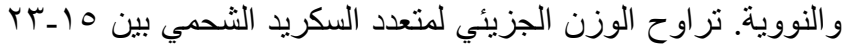

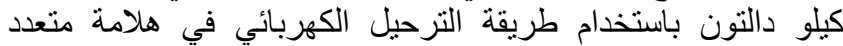

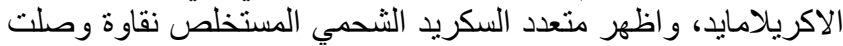

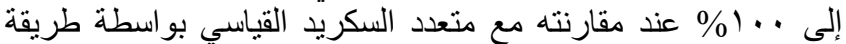

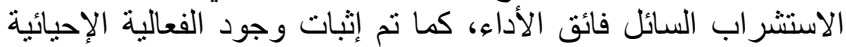

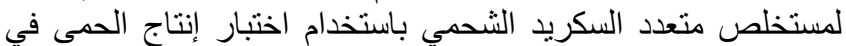

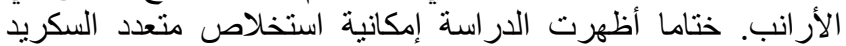

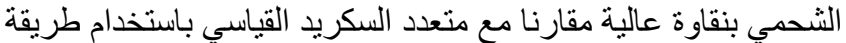

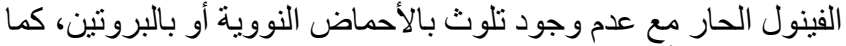

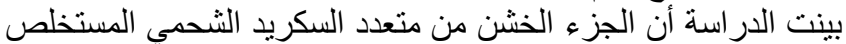

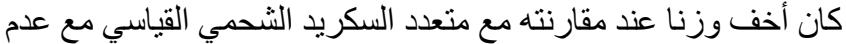
وجود تأثثير مثبط لفعاليته البيولوجية التي بقيت سليمة. 